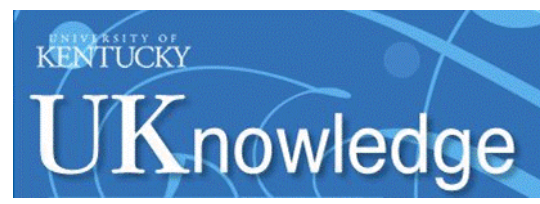

University of Kentucky

UKnowledge

\title{
Investigation of Factors That Influence Public Librarians' Social Media Use for Marketing Purposes: An Adoption of the Technology Acceptance Model and Theory of Planned Behavior
}

\author{
Soohyung Joo \\ University of Kentucky, soohyung.joo@uky.edu \\ Namjoo Choi \\ University of Kentucky, namjoo.choi@uky.edu \\ Lindsey M. Harper \\ Marshall University
}

Follow this and additional works at: https://uknowledge.uky.edu/slis_facpub

Part of the Library and Information Science Commons, and the Marketing Commons

Right click to open a feedback form in a new tab to let us know how this document benefits you.

\section{Repository Citation}

Joo, Soohyung; Choi, Namjoo; and Harper, Lindsey M., "Investigation of Factors That Influence Public Librarians' Social Media Use for Marketing Purposes: An Adoption of the Technology Acceptance Model and Theory of Planned Behavior" (2019). Information Science Faculty Publications. 71.

https://uknowledge.uky.edu/slis_facpub/71

This Article is brought to you for free and open access by the Information Science at UKnowledge. It has been accepted for inclusion in Information Science Faculty Publications by an authorized administrator of UKnowledge. For more information, please contact UKnowledge@lsv.uky.edu. 


\section{Investigation of Factors That Influence Public Librarians' Social Media Use for Marketing Purposes: An Adoption of the Technology Acceptance Model and Theory of Planned Behavior}

Digital Object Identifier (DOI)

https://doi.org/10.1086/702198

Notes/Citation Information

Published in The Library Quarterly, v. 89, no. 2.

(C) 2019 by The University of Chicago. All rights reserved.

The copyright holder has granted the permission for posting the article here. 


\title{
Investigation of Factors That Influence Public Librarians' Social Media Use for Marketing Purposes: An Adoption of the Technology Acceptance Model and Theory of Planned Behavior
}

\author{
Soohyung Joo, Namjoo Choi, and Lindsey M. Harper
}

\begin{abstract}
This study aims to explore multiple factors that are associated with social media use by public librarians for marketing purposes. Based on the technology acceptance model and theory of planned behavior, the effects of five factors-usefulness, ease of use, attitude, subjective norms, and behavioral control—on social media use intention were examined. A survey was conducted, and 462 valid responses were collected from public librarians across the United States. The findings revealed that all five factors have a significant impact on librarians' intention to engage in social media activities for library marketing. Perceived behavioral control factors were the most influential on social media use intention. Both practical and theoretical implications are discussed based on the findings of this study.
\end{abstract}

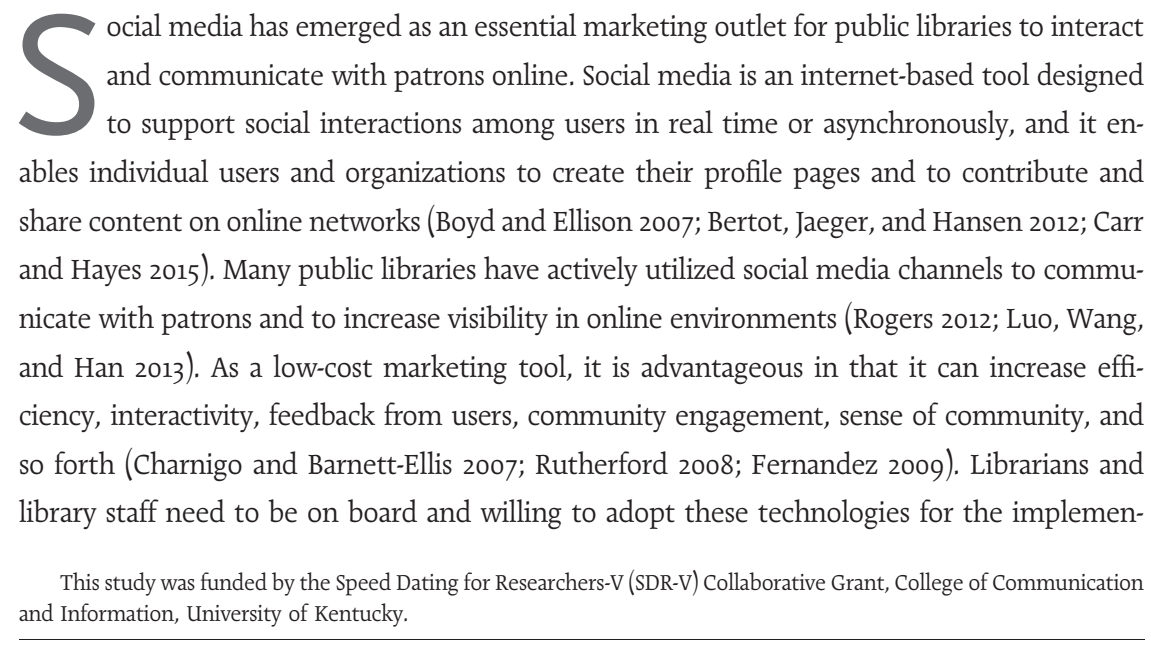

Library Quarterly: Information, Community, Policy, vol. 89, no. 2, pp. 137-155. (C) 2019 by The University of Chicago. All rights reserved. $0024-2519 / 2019 / 8902-0004 \$ 10.00$ 
tation of these platforms to be successful (Smeaton and Davis 2014). This can be facilitated by understanding and identifying the factors that contribute to librarians' adoption of social media tools for library marketing.

Researchers recognize the benefits of social media as a marketing tool and have investigated different aspects of social media use in library contexts. Prior studies explored not only the content of social media posts in public libraries but also librarians' perceptions of social media marketing (e.g., Rutherford 2008; Anttiroiko and Savolainen 2011; Aharony 2012). Efforts have been made to create practical guidelines and best practices useful for social media marketing in public libraries (e.g., Steiner 2012; Tomlin 2014); however, less research has tried to understand the multiple factors that are associated with public librarians' engagement in social media activities, including the platform's ease of use and usefulness toward reaching libraries' target audiences. Given the benefits of social media as an effective marketing platform for public libraries, this study aims to understand a variety of factors that would affect public librarians' intention to use social media for their library's marketing, including attitude about social media use, which is influenced by its ease of use and usefulness, in addition to behavioral control factors and social norms. As a theoretical framework, this study employs two existing theories related to behavioral intention to understand the factors associated with public librarians' adoption of social media platforms to promote their libraries' services: the technology acceptance model (TAM) and the theory of planned behavior (TPB). Using a combined TAM and TPB model can facilitate a greater understanding of technology-specific factors associated with adopting a technology-related behavior. The results from the present study using the combined model have several practical implications, which will be useful to better facilitate the use of social media for public libraries' marketing purposes.

\section{Literature Review}

\section{Social Media Marketing in Public Libraries}

The use of social media platforms is a low-cost tool that public libraries can adopt to increase the marketing of the organization's services (Dankowski 2013; Fasola 2015; Phillips 2015). These platforms make it possible for libraries to disseminate information about the organization (Neo and Calvert 2012; Shiri and Rathi 2013), to engage with their communities (Rutherford 2008; Smeaton and Davis 2014; Cavanagh 2016), to increase website traffic (Dankowski 2013), and to advocate for the library (Phillips 2015). In a survey of public libraries in the United States, early adopters of social technologies had more users visit the library and utilize its resources and services (Lietzau and Helgren 2011).

A successful marketing strategy for libraries that elect to implement these tools involves clearly defining the organization's target audience, advertising its services, and providing consistent information, assistance, and support for its users (Rutherford 2008). The use of these strategies enables public libraries to reach users in their preferred online environment, which 
considerably benefits digital natives (Neo and Calvert 2012). These marketing strategies demonstrate the library's importance and relevance to individuals who may not otherwise have had exposure to the organization's services (Phillips 2015; Cavanagh 2016).

In Web 2.o's early days, some public libraries adopted social technologies for four main reasons: content sharing, communication, social networking, and crowdsourcing (Anttiroiko and Savolainen 2011). Noa Aharony (2012) explored Facebook accounts of 10 public libraries of various sizes in the United States; results indicated that almost half of all posts emphasized library-related activities. In an analysis of tweets by the Edmonton Public Library (Shiri and Rathi 2013), most posts were associated with information sharing, reading recommendations, and advisory services. Similarly, content analyzed by Abigail L. Phillips (2015) indicated that libraries were using social media to market programming, literacy advocacy, and access issues. These studies demonstrate some of the ways public libraries have adopted social media to be able to market their services to their users.

\section{Librarian Perception of Social Media Use in Public Libraries}

Librarians spend a considerable amount of their workday maintaining and updating their libraries' social media pages (Vucovich et al. 2013; Phillips 2015). Public librarians recognize the importance that marketing their services on social media has for their organization (Rutherford 2008); however, the number of platforms to choose from can leave some librarians reluctant to incorporate these media into their everyday services. Reluctance by staff was often cited as a reason why public librarians are hesitant to adopt social media to promote library services (Rutherford 2008; Smeaton and Davis 2014; Carlsson 2015). To reduce staff reluctance, it is important to consider the learning curve associated with using these platforms and to provide workshops or training to acclimate librarians and library staff to these social media technologies (Rutherford 2008; Mansor and Idris 2010).

Louise L. Rutherford (2008) interviewed seven key staff members in public libraries in the United States and New Zealand and discovered that in addition to staff reluctance, lack of staff and administrative support also created barriers to successful social media implementation. Similarly, Kathleen Smeaton and Kate Davis (2014) discovered that negotiating expectations of use with these technologies can posit additional challenges for librarians. Among public libraries in Oyo State, Nigeria, $62.1 \%$ had unfavorable perceptions of the use of social media technologies to promote library services. The justifications provided for these views included the lack of visibility of public libraries in Nigeria, patron type, and the notion that social media cannot replace the traditional means of providing library services (Fasola 2015).

In a case study of two public libraries in Australia, individuals who had extensive knowledge of social media for personal use were more likely to accept social media as a service channel for marketing the library (Smeaton and Davis 2014). Librarians between the ages of 20 and $40(82.7 \%)$ across various library types had a positive perception of using social media tools to 
promote library services (Fasola 2015). Similarly, Phillips (2015) investigated mostly younger public and school librarians' perceptions of social media use, and $85 \%(n=46)$ agreed that maintaining social media accounts for their libraries ought to be part of their professional responsibilities. Samuel Kai-Wah Chu and Helen S. Du (2013) surveyed 38 academic librarians, and results demonstrated a trend of more positive perceptions toward using social media to engage with patrons and to promote library services. Furthermore, in an analysis of 44 articles across various LIS journals, results indicate that most public librarians welcome social media tools; however, institutional barriers and failure to recognize the validity of these platforms could harm the technology's implementation (Carlsson 2015). Staff acceptance of changing roles and willingness to adopt new technologies are critical for social media integration's success (Smeaton and Davis 2014).

\section{Technology Acceptance Model}

The TAM examines the impact that ease of use and usefulness has toward technology use. Under this model, individuals are more likely to adopt a technology when it is useful, but only when the technology is also easy to use. Technology is less likely to be adopted if it is not useful, even if it is easy to use (Davis 1989). Fred. D. Davis (1989) defined usefulness as "the degree to which a person believes that using a particular system would enhance his or her job performance" (320) and perceived ease of use as "the degree to which a person believes using a particular system would be free of effort” (320). See the TAM outline in figure 1 for a visual representation of this model.

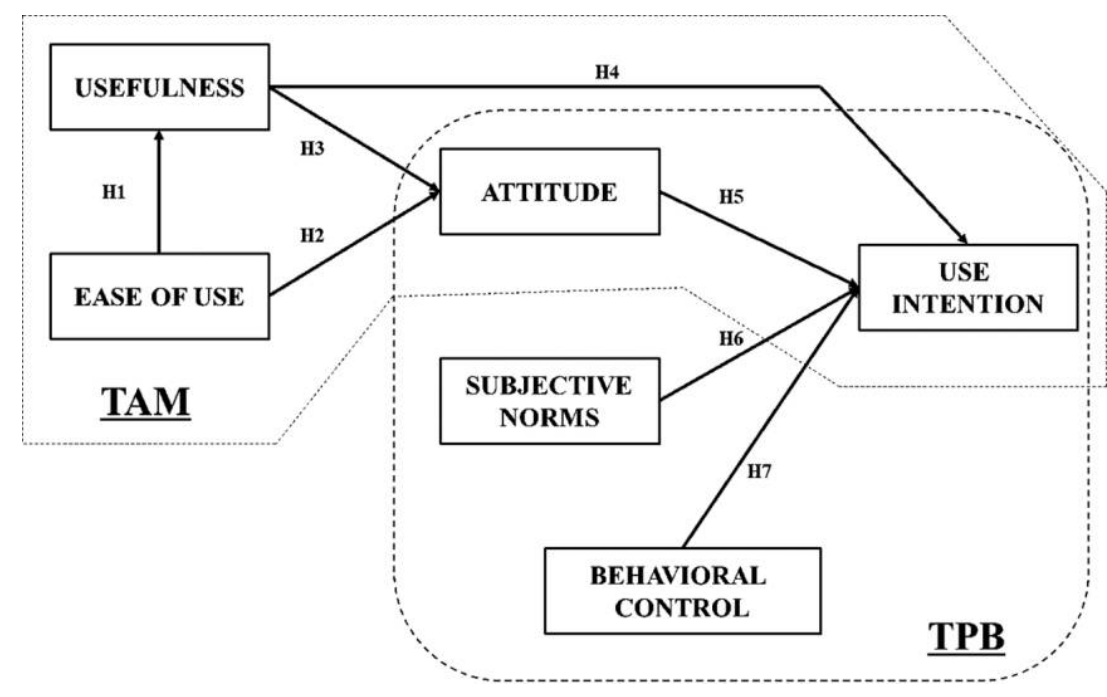

Figure 1. Model representations and hypotheses: the technology acceptance model and the theory of planned behavior. 
TAM has been used to examine the selection of different technologies in diverse information systems (IS) situations (Chuttur 2009). There has been an increase in organizations that adopt social media because of its ease of use, its immediacy for publishing content, and its useful platform for interacting with library users (Fasola 2015). An example of TAM being employed is a survey of undergraduates in the United States $(n=332)$ about the factors that affect the selection of online library resources. Results from this study demonstrated that usefulness and ease of use positively influenced attitude toward using online library resources, and that in turn created a positive behavioral intention toward adopting these technologies (Joo and Choi 2015).

\section{Theory of Planned Behavior}

The TPB is a social psychology theory that explains human behavior and behavioral intention across different situations (Fishbein and Ajzen 1975; Ajzen 1991). This theory posits that behavioral intention is influenced by attitude, subjective norms, and perceived behavioral control factors about a given behavior. Subjective norms are described as an individual's perception of others' views of certain behaviors. If a behavior, or adoption of social media tools in our case, is perceived to be an accepted behavior by colleagues or peers, a person is more likely to perform the behavior. Perceived behavioral control refers to an individual's "perception of the ease or difficulty of performing the behavior of interest" (Ajzen 1991, 183). See the TPB outline in figure 1 for a visual representation of this model.

The TPB has been used to combat problems in various fields, including public health issues such as condom use (Albarracín et al. 2001), mental health issues such as whether someone seeks help from a professional (Chen, Romero, and Karver 2016), and social media issues such as privacy protection (Saeri et al. 2014). As it pertains to libraries, Chun-Hua Hsiao and Kai-Yu Tang (2014) investigated college students' behavioral intentions to adopt e-books in a library setting using the TPB. The results of this research demonstrate that social norms significantly affect behavioral intention, whereas perceived behavioral control did not significantly affect behavioral intention. Yasser D. Al-Otaibi and Luke Houghton (2015) used a version of the TPB to examine the factors that influence Australian university students to adopt Web 2.0 technologies to influence in-class learning. Their results indicate that students' attitudes, social norms, and perceived behavioral control factors had a significant positive effect on behavioral intention to adopt Web 2.o technologies.

\section{Combined TAM-TPB}

Shirley Taylor and Peter A. Todd (1995a) proposed combining elements from TAM and TPB models to measure information technology usage behaviors, as the addition of subjective norms and behavioral control factors can significantly influence these behaviors. In this model, perceived usefulness and ease of use determine attitude toward using the technology, and attitude influ- 
ences behavioral intention to adopt the technology. Subjective norms and perceived behavioral control factors influence behavioral intention. The model confirmed usefulness and ease of use had a significant positive impact on attitude toward adopting technology, and attitude had a significant positive influence on behavioral intention. Subjective norms and perceived behavioral control factors had a significant positive influence on behavioral intention. See figure 1 for a visual example of our complete model.

Previous research has utilized a combined TAM-TPB model to solve many information problems. Jeroen Schepers and Martin Wetzels (2007) conducted a meta-analysis that examined 51 articles containing 63 studies about the overall influence subjective norms have on TAM-based research. The results confirmed that subjective norms had a significant positive influence on behavioral intention to adopt new technologies. Sultan M. Al-Daihani (2016) used a modified version of TAM to determine factors that influence students' decisions to adopt Twitter as an information resource. The results indicated that perceived usefulness and social norms had a significant positive influence on behavioral intention to adopt Twitter, but ease of use was not a significant predictor for intention. Qijun Xie and colleagues (2017) studied the factors that determine citizens' intentions to use e-government resources using TAM and TPB separately. Results from the TAM components demonstrated that perceived usefulness had a significant positive impact on attitude and behavioral intention, and perceived ease of use had a significant positive influence on perceived use and attitude formation. Results from the TPB components indicated that attitude, social norms, and perceived behavioral control had a significant positive influence toward intention to use e-government resources. In the context of technology usage behaviors, the combined model provides a more holistic picture of the factors that can affect someone's decision to engage in technology-related behaviors. Improving an already useful technology's ease of use would reduce the effort expectancy associated with it and, in the context of our study, would likely create more favorable attitudes about implementing these technologies in the library setting.

\section{Research Model and Hypotheses}

This study adopted the combined TAM and TPB (Taylor and Todd 1995a) to understand social media use for library marketing among public librarians. The underlying theoretical framework of this study is the ТРВ (Ajzen 1991), which analyzes the effects of individual librarians' attitude, subjective norms, and behavioral control on the intention to use social media for library marketing. Then, the TAM (Davis 1989) was augmented to further explore the factors of perceived usefulness and ease of use. In our study's context, the addition of the TAM to the TPB reveals additional motivating factors that can influence a librarian's attitude formation, particularly in the context of technology usage. Therefore, this model's significance provides an extended understanding about some of the additional factors that can influence a librari- 
an's attitude formation regarding social media use for library-related marketing. Figure 1 presents the research model, and the following hypotheses guided this study:

H1: Perceived ease of use of social media positively affects a public librarian's perception of usefulness of social media for library marketing.

H2: Perceived ease of use of social media positively affects a librarian's attitude toward social media use for library marketing.

H3: Perceived usefulness of social media positively affects a librarian's attitude toward social media use for library marketing.

$\mathrm{H}_{4}$ : Perceived usefulness of social media positively affects a librarian's intention to use social media for library marketing.

H5: Positive attitude toward social media use positively affects a librarian's intention to use social media for library marketing.

H6: Subjective norms positively affect a librarian's intention to use social media for library marketing.

H7: Behavioral control positively affects a librarian's intention to use social media for library marketing.

In this study, we operationally define "attitude" as a librarian's perceived positive or negative view of social media use for marketing. According to both the TAM and TPB, an individual's positive or negative evaluation of attitude leads to the formation of behavioral intention (Davis 1989; Ajzen 1991). We assumed that a librarian who has a positive attitude toward social media use is more likely to utilize social media for library marketing $\left(\mathrm{H}_{5}\right)$. We further examined the two factors associated with attitude based on the TAM. In this study, "perceived usefulness" refers to the degree to which a librarian perceives that using social media would enhance his or her library's capability of marketing to reach patrons. Based on the TAM (Davis 1989), we assumed that perceived usefulness would be a critical factor that accounts for a librarian's attitude toward social media use as well as her or his use intention ( $\mathrm{H}_{3}$ and $\left.\mathrm{H}_{4}\right)$. In addition, we presumed that a librarian's perceived ease of use would lead to a positive attitude toward social media use as well as a perception of usefulness ( $\mathrm{H}_{1}$ and $\left.\mathrm{H}_{2}\right)$. If social media is easier to use to engage with a larger audience compared with traditional marketing methods (e.g., printed posters or community newspapers), then librarians will form a positive attitude toward social media and perceive it as a useful tool.

According to the TPB, subjective norms refer to an individual's perception of others' views or judgment of certain behaviors (Ajzen 1991). Thus, in this study, subjective norms concern a librarian's perception about social media use that could be influenced by judgment of other librarians or staff. The factor of subjective norms has been understudied in prior research regarding social media use in public libraries. If social media marketing is perceived to be com- 
mon practice in the public library community, an individual librarian might be more likely to engage in social media use for his or her library. Thus, we assumed other librarians' perception of social media marketing would influence a librarian's intention to engage with social media practices (H6).

Finally, based on the TPB (Ajzen 1991), we operationally defined perceived behavioral control as a librarian's perception of the ease or difficulty of using social media for library marketing. Behavioral control is closely related to skills, knowledge, or ability required to use social media (Lau 2011; Cheon et al. 2012); therefore, we assert that behavioral control would affect a librarian's intention to use social media for marketing $\left(\mathrm{H}_{7}\right)$.

\section{Research Method}

\section{Data Collection}

To empirically test the research hypotheses, we conducted a survey and analyzed the data using inferential statistics - to be more specific, structural equation modeling (SEM). First, we manually visited 50 state library departments' websites in the United States to locate their library directories containing the email addresses of the state's public library directors and librarians. From 25 state library directories, we obtained a total of 4,252 public library directors' or librarians' e-mail addresses. The initial survey invitation (February 4, 2016) and two subsequent reminders (February 8 and 15, 2016) were then emailed to the public library directors and librarians, in which we asked them to forward the invitation to the staff member who is responsible for social media in their library. Thus, each response reflects one library. The survey ran for 2 weeks and was closed on February 19, 2016. As an incentive, survey participants had the opportunity to register in a drawing for one of five $\$ 50$ Amazon gift cards.

In total, 462 valid responses were collected and analyzed. As shown in table 1 , we collected responses from different public libraries varying in size. Regarding social media tools adopted, 98.1\% of the participants' libraries used Facebook, followed by Twitter (47.2\%), Pinterest (36.8\%), and Instagram (26.6\%). Most libraries used multiple social media platforms.

Table 1. Responses by Library Service Population

\begin{tabular}{lrcc}
\hline Service Population & $n$ & $\%$ & $\begin{array}{c}\text { Number of Social Media Tools, } \\
\text { Mean (SD) }\end{array}$ \\
\hline 2,500 & 86 & 18.6 & $1.74(1.21)$ \\
$2,500-9,999$ & 119 & 25.8 & $2.14(1.30)$ \\
$10,000-24,999$ & 113 & 24.5 & $2.98(1.75)$ \\
$25,000-49,999$ & 57 & 12.3 & $3.07(1.36)$ \\
$\geq 50,000$ & 87 & 18.8 & $4.20(2.03)$ \\
\cline { 2 - 4 } Total & 462 & 100.0 & $2.77(1.77)$ \\
& & &
\end{tabular}




\section{Measures}

An online survey was developed for two research objectives, and this study concerns one of those two. As mentioned in the introduction, the goal of this article is to explore multiple factors associated with librarians' intention to use social media for marketing purposes by adopting existing relevant theories. The other paper aims to examine public libraries' challenges, motivators, and perceptions (i.e., perceived importance and future use intention) toward the use of social media for marketing. The measurement items for this article in the survey questionnaire were developed by adopting and modifying empirically validated scales from previous studies (Ajzen and Fishbein 2005; Taylor and Todd 2005b; Park et al. 2009; Tohidinia and Mosakhani 2010; Xu, Benbasat, and Cenfetelli 2013; see table A1). The specific measurement items, all of which were measured on a 7-point Likert scale, are provided together with their corresponding sources in table A1.

\section{Data Analysis and Results}

Partial least squares (PLS), a component-based SEM technique, was employed for measurement validation and structural model testing (Chin 1998). PLS was chosen over a covariancebased SEM because the focus of this study is more on exploration than confirmation (Hair, Ringle, and Sarstedt 2011).

As shown in table 2, the Cronbach's alpha and composite reliability scores of all constructs exceeded .70, indicating adequate internal consistency (Fornell and Larcker 1981). Also, all item loadings were above .70 with significance at the .01 level, suggesting convergent validity (Comrey 1973). All average variance extracted scores (see table 2) were above .50, providing additional support for convergent validity (Fornell and Larcker 1981). Last, the square roots of the average variance extracted scores (the diagonal elements in table 2) were higher than the interconstruct correlations, confirming discriminant validity (Fornell and Larcker 1981).

Table 2. Reliability and Validity of Measurement

\begin{tabular}{|c|c|c|c|c|c|c|c|c|c|c|c|}
\hline & Mean & SD & $\mathrm{AL}$ & $C R$ & AVE & ATT & $\mathrm{BC}$ & INT & EOU & UF & SN \\
\hline ATT & 5.95 & .75 & .83 & .90 & .75 & .87 & & & & & \\
\hline$B C$ & 5.57 & 1.16 & .95 & .96 & .87 & .26 & .93 & & & & \\
\hline INT & 6.09 & .89 & .92 & .95 & .86 & .48 & .57 & .93 & & & \\
\hline EOU & 5.23 & 1.06 & .74 & .85 & .65 & .57 & .27 & .35 & .81 & & \\
\hline UF & 5.84 & .85 & .89 & .93 & .81 & .65 & .25 & .41 & .48 & .90 & \\
\hline SN & 5.94 & .80 & .80 & .87 & .70 & .29 & .21 & .29 & .15 & .27 & .84 \\
\hline
\end{tabular}

Note. $-\mathrm{AL}=$ Cronbach's alpha; $\mathrm{CR}=$ composite reliability; $\mathrm{AVE}=$ average variance extracted; $\mathrm{ATT}=$ attitude; $\mathrm{BC}=$ behavioral control; INT = use intention; $\mathrm{EOU}=$ ease of use; UF = usefulness; $\mathrm{SN}=$ subjective norm. 
Harman's single-factor test was performed to check for any common method variance (Podsakoff et al. 2003). None of the factors explained the majority of the covariance, indicating that common method bias is not a concern in this study.

As shown in figure 2, all path coefficients were significant as hypothesized. In the TAM part of the research model, both usefulness $(\beta=.483, p<.01)$ and ease of use $(\beta=.339, p<.01)$ had positive effects on attitude, accounting for $50.6 \%$ of the variance in attitude. Attitude, in turn, was also found to positively influence use intention $(\beta=.277, p<.01)$. The paths hypothesized based on TPB also received empirical support. In particular, the effects of subjective norms $(\beta=.094, p<.05)$ and behavioral control $(\beta=.457, p<.01)$ on use intention were significant and, combined with attitude, explained $46.0 \%$ of the variance in use intention. Note that the influences of both usefulness and subjective norms on use intention (i.e., $\beta=.094, p<.05$ ) were close to $o$ and thus had weak relationships (Hair et al. 2014, 171). This indicates that their effects on use intention are minimal compared with those of attitude and behavioral control. In addition, the $R^{2}$ value of use intention, which reflects the total effects of our combined TAM-TPB model, was .460. According to Hair et al. (2011, 145), although acceptable $\mathrm{R}^{2}$ values vary by research discipline and model complexity, it suggests that the model's predictive accuracy can be described as moderate.

\section{Discussion}

Based on the combined TAM-TPB model, this study explored multiple factors that affect librarians' intention of social media use for library marketing. SEM, a type of inferential statistic, was applied to empirically prove the hypotheses in the research model. This study confirms a pos-

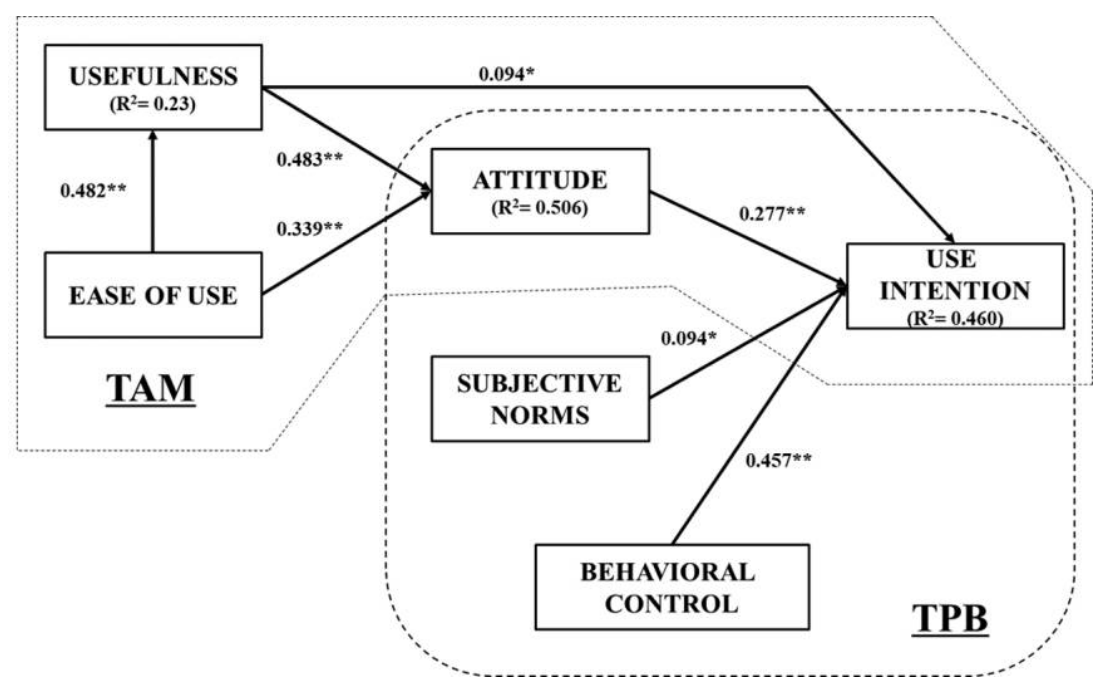

Figure 2. SEM analysis results. $* p<.05 . * * p<01$ 
itive causal relationship between a librarian's attitude toward social media and his or her intention to use it. Prior studies revealed that public librarians generally tend to be positive about adopting social media for their libraries (e.g., Chu and Du 2013; Carlsson 2015); however, the staff's willingness to adopt social media would be critical for successful integration of social media for their libraries (Smeaton and Davis 2014).

The results of the study also confirm that both perceived usefulness and ease of use had moderately positive impacts on attitude. The combination of these factors led to an intention to use social media for library marketing. This implies that librarians who perceive social media as useful and easy to use are likely to hold favorable attitudes toward using social media marketing for their library. When selecting social media tools, libraries ought to assess which tools would be the most effective for marketing purposes and which would be deemed the most efficient and easy to use from the perspective of staff. An additional point to consider is which social media platforms are being used by the library's target audience (e.g., Instagram or Facebook). As a way to enhance the effectiveness of social media, it is important to utilize the tool to interact with patrons in diverse ways, such as knowledge gathering and sharing, community engagement, soliciting feedback, engaging discussion, and sharing or creating cultural and educational activities (e.g., Cahill 2011; Chen, Chu, and Xu 2012; Shiri and Rathi 2013; Madge and Coşerea 2014), rather than just announcing events at the library. One of the strengths of social media is its interactivity and two-way communications compared with traditional marketing channels (e.g., printed posters, newsletters). Without taking into consideration the library's target audience, however, librarians could be speaking on a platform with no "followers."

Social media's ease of use is a construct of which the library has no control, as it is more related to the system features of a platform's interface. Perceived ease of use is partially related to users' familiarity with these social media tools; therefore, when libraries consider which tools to use, they ought to consider which platforms librarians prefer and have prior experience using. Reluctance to use social media may be due to unfamiliarity with the platform. "Familiarity," in this context, is described as the extent to which individuals have an understanding of social media platforms through direct and indirect exposure (Sánchez-Franco and Roldán 2015). As a way to combat the often ever-changing nature of social media, it is important that librarians explore these technologies not only for their library, but for their own personal use, as additional exposure to the social media platform will allow librarians to become more familiar with the interface (ultimately making it easier to use), and in turn see the ways it can serve as useful (both personally and professionally). Although personal use of social media is not a requirement to use social media in the library setting, further familiarity will aid in reducing the social media platform's complexity. Acquiring training to use these platforms is another option in assisting librarians and staff to more easily navigate these social media tools. The results from the present study affirm the significant relationship between ease of use and useful- 
ness. That is, social media platforms can be deemed more useful if librarians are more comfortable with using these tools. By providing relevant training, librarians can not only more easily use these platforms, but also perceive them as more useful, which eventually leads to more engagement in social media activities.

One of the unique contributions of this study lies in that we included the factor of subjective norms in understanding social media adoption in the public library context. Prior studies explored various motivators for social media use in public libraries, but few of them investigated the impact of subjective norms. The results from the present study indicate a significant effect of subjective norms on the use intention of social media, but its effect was relatively small $(\beta=.094, p<.05)$ compared with the other two TPB factors. This implies that subjective norms act as a motivator for public librarians to increase their intention to use social media for marketing, but it might not be a primary reason. That is, public librarians tend to be more influenced by their attitude toward social media or perceived behavioral control rather than the views of other librarians. Although the impact of subjective norms is minor, it would still be worthwhile for public libraries to share best practices with their staff as a way to instill subjective norms and to update them with what other libraries do for social media marketing. Social media marketing for libraries is an efficient and low-cost tool that requires less effort and time compared with traditional methods of marketing such as printed posters and community newsletters. It also enables libraries to more immediately reach their target audience, check notifications, and respond to feedback from patrons in a more timely manner. If libraries continue to make staff aware of the benefits of social media marketing through internal training and workshops, they will be more likely to increase the profession's subjective norms and to participate in more social media activities.

Perceived behavioral control was the most influential on librarians' intention to use social media in public libraries $(\beta=.457, p<.01)$. Behavioral control is closely related to skills and knowledge required to use and manage social media (Lau 2011). Librarians with more social media knowledge and experience are more likely to adopt it for library services; therefore, the skills of library staff would be a key contributing factor to the success of social media use in public libraries (Smeaton and Davis 2014). At the same time, this also means that librarians with limited skills might be reluctant to use social media for their libraries. Lack of skills and expertise in managing social media tools can be a critical barrier in the use of social media for library marketing purposes (Chu and Du 2013). As a way to reduce staff reluctance, it is important to provide adequate training or workshops to enhance their practical skills and knowledge in using social media for marketing purposes. Again, training is one of the key factors that can promote the implementation of emerging technologies in library environments (Mansor and Idris 2010).

The contributions of this study extend beyond the empirical findings. To the best of our knowledge, this study is one of the first to employ the combined TAM-TPB model to under- 
stand multiple factors around social media use in public library environments. Both TAM and TPB have been proven as valid theoretical frameworks that are applicable to explain behavioral intention in different contexts of library services (e.g., Thong, Hong, and Tam 2002; Hsiao and Tang 2014; Joo and Choi 2015). As it is in the TPB, the three exogenous factors, including attitude, subjective norms, and behavioral control, explain public librarians' intention to use social media for library marketing, accounting for around $46 \%$ of the variance. The addition of the TAM to the TPB extended the scope of the research model by further delving into the factors of perceived usefulness and ease of use. The strength of the combined TAM-TPB lies in that it constructs a second-order model to understand additional factors that elucidate a librarian's positive or negative attitude toward social media marketing. The combined TAMTPB fits the context of social media use in public libraries as it provides an extended understanding of multiple factors in relation to librarians' social media use for marketing purposes.

However, the theoretical assumptions of this study, that is, the combined TAM-TPB, do not look into negative factors such as challenges or problems in the use of social media marketing in public libraries. Because the nature of these two theoretical frameworks is to explain factors that positively influence behavioral intention, negative factors such as the challenges or problems associated with social media usage are not included in the research design. However, considering these negative factors would offer a more nuanced view of social media adoption in public libraries.

Most of the previous literature has focused on the positive aspects of social media use in public libraries while neglecting its potential problems and limitations. Despite many benefits of social media, there are some limitations and potential problems to think about in the application of social media in the public library environment. First, even though social media is relatively low-cost, it still requires considerable effort and staff time to create content and to interact with users (Jones and Harvey 2016). Particularly, individual libraries might need to continuously monitor potential negative user comments, complaints, or misleading content, and need to strategize how to resolve any unexpected user responses. Second, the use of social media in the public library setting can be an extra burden on the employee to develop separate strategies or content for social media marketing in addition to the traditional marketing, which is especially true for small libraries with limited resources or staff time. A third problem we need to consider is privacy concerns or accidental release of some confidential information. Social media use involves new challenges related to privacy, security, and other information policy issues in organizations (Bertot et al. 2012). Public libraries might not be free from the privacy-related concerns while using social media. For example, many libraries upload and share pictures of their events or programming that include participants (often minors), attendees, or volunteers. Finally, as shown in the Facebook-Cambridge Analytica data scandal in 2018 (Solon 2018), social media tools themselves cannot guarantee the rights of privacy and the protection of confidential information. Obviously, these kinds of negative factors would 
have impacts on social media adoption in public libraries, and they are very important to further discuss to understand the entire sphere of social media practice in public libraries.

There are also several other frameworks in IS research that could be helpful in exploring other relevant questions. For example, another well-known framework in IS research is IS success theory by W. H. DeLone and E. R. McLean (1992). This theory includes constructs such as information quality and systems quality, and employing these success factors would help generate further practical insights.

\section{Conclusion}

Based on the combined TAM-TPB model, the researchers empirically investigated five factorsusefulness, ease of use, attitude toward social media use, subjective norms, and behavioral control-that would affect librarians' intention to use social media for marketing in public libraries. The findings revealed that all five factors would have a significant impact on social media use intention directly or indirectly. Behavioral control was the most influential determinant on the use intention whereas subjective norms were the least influential. The implications of the study highlight the importance of training librarians in the skills required for using social media tools, including effectively using these platforms in a diverse range of interactions with patrons.

This present study has some limitations. First, this study did not investigate organizationlevel factors, such as administrative support, library-level climate toward social media, or related library resources. Second, even though we empirically tested the research model, we did not provide specific examples of the identified factors that would influence librarians' behavioral intention. Third, this study examined only motivational factors of social media practice for library marketing. As discussed, however, social media use has several negative aspects or problems in the public library context. The current study neglects the negative impacts or issues with using social media, which are critical to understanding social media use and adoption in public libraries. These limitations illustrate a need for further research that includes library-level factors-in particular, the relationship between library-level support, resources, and social media activities. Future research is also encouraged to investigate the challenges and negative factors associated with the use of social media in the public library setting. Particularly, we plan to examine the relationship between privacy and security concerns and attitude toward social media use. Future research ought to involve a qualitative approach to supplement the quantitative findings in order to gain a better understanding of the underlying reasons for social media use in public libraries. 


\section{Appendix}

Table A1. Research Constructs and Measures

\begin{tabular}{|c|c|c|}
\hline Construct & Measure & Source \\
\hline Usefulness & $\begin{array}{l}\text { Social media improves the quality } \\
\text { of library marketing } \\
\text { Social media helps to build stronger } \\
\text { relationships with library users } \\
\text { Social media enhances the } \\
\text { effectiveness of library marketing }\end{array}$ & $\begin{array}{c}\text { Davis (1989); Thong et al. (2002); } \\
\text { Park et al. (2009) }\end{array}$ \\
\hline Ease of use & $\begin{array}{l}\text { Social media facilitates library } \\
\text { marketing with minimal resources } \\
\text { Social media reduces the time and } \\
\text { effort the library spends on } \\
\text { marketing activities } \\
\text { Social media makes it easy to reach } \\
\text { out to library users }\end{array}$ & $\begin{array}{c}\text { Davis (1989); Thong et al. (2002); } \\
\text { Park et al. (2009) }\end{array}$ \\
\hline Attitude & $\begin{array}{l}\text { Social media use for public library } \\
\text { marketing is valuable } \\
\text { Social media use for public library } \\
\text { marketing is desirable } \\
\text { Social media use for public library } \\
\text { marketing is pleasant }\end{array}$ & $\begin{array}{l}\text { Ajzen and Fishbein (2005); } \\
\text { Thong et al. (2002); } \\
\text { Park et al. (2009) }\end{array}$ \\
\hline Subjective norms & $\begin{array}{l}\text { Social media marketing is a common } \\
\text { practice among public libraries } \\
\text { It is expected that public libraries } \\
\text { should use social media to reach } \\
\text { out to community users } \\
\text { Many public libraries are actively } \\
\text { utilizing social media for marketing }\end{array}$ & $\begin{array}{l}\text { Ajzen (1991); Tohidinia } \\
\text { and Mosakhani (2010) }\end{array}$ \\
\hline Behavioral control & $\begin{array}{l}\text { I have the skills necessary to use } \\
\text { social media for library marketing } \\
\text { I have the knowledge necessary to use } \\
\text { social media for library marketing } \\
\text { I am familiar with using social } \\
\text { media for library marketing } \\
\text { I am experienced with using social } \\
\text { media for library marketing }\end{array}$ & $\begin{array}{c}\text { Ajzen and Fishbein (2005); } \\
\text { Taylor and Todd (1995b); } \\
\text { Tohidinia and Mosakhani (2010) }\end{array}$ \\
\hline Use intention & $\begin{array}{l}\text { I am likely to actively engage in social } \\
\text { media marketing in my library } \\
\text { I intend to participate in social media } \\
\text { activities for library marketing } \\
\text { I will upload posts to social media } \\
\text { channels for my library marketing }\end{array}$ & $\begin{array}{l}\text { Ajzen and Fishbein (2005); Xu, } \\
\text { Benbasat, and Cenfetelli (2013) }\end{array}$ \\
\hline
\end{tabular}




\section{References}

Aharony, Noa. 2012. "Facebook Use in Libraries: An Exploratory Analysis." Aslib Proceedinas 64 (4): 358-72. Ajzen, Icek. 1991. "The Theory of Planned Behavior." Oraanizational Behavior and Human Decision Processes 50 (2): 179-211.

Ajzen, Icek, and Martin Fishbein. 2005. “The Influence of Attitudes on Behavior.” In The Handbook of Attitudes, edited by Dolores Albarracin, Blair T. Johnson, and Mark P. Zanna. London: Psychology.

Albarracín, Dolores, Blair T. Johnson, Martin Fishbein, and Paige A. Muellerleile. 2001. "Theories of Reasoned Action and Planned Behavior as Models of Condom Use: A Meta-analysis." Psucholoaical Bulletin 127 (1): 142-61.

Al-Daihani, Sultan M. 2016. "Students' Adoption of Twitter as an Information Source. An Exploratory Study Using the Technology Acceptance Model." Malausian Iournal of Library and Information Science 21 (3): 57-69.

Al-Otaibi, Yasser D., and Luke Houghton. 2015. "Examining the Theoretical Factors That Influence University Students to Adopt Web 2.0 Technologies: The Australian Perspective.” International Journal of Information and Communication Technoloay Education 11 (1): 1-26.

Anttiroiko, Ari-Veikko, and Reijo Savolainen. 2011. "Towards Library 2.0: The Adoption of Web 2.0 Technologies in Public Libraries." Libri 61 (2): 87-99.

Bertot, John Carlo, Paul T. Jaeger, and Derek Hansen. 2012. "The Impact of Policies on Government Social Media Usage: Issues, Challenges, and Recommendations." Government Information Ouarterly 29 (1): 30-40.

Boyd, Danan M., and Nicole B. Ellison. 2007. "Social Network Sites: Definition, History, and Scholarship." Lournal of Computer-Mediated Communication 13 (1): 210-30.

Cahill, Kay. 2011. “Going Social at Vancouver Public Library: What the Virtual Branch Did Next.” Proaram $45(3): 259-78$

Carlsson, Hanna. 2015. "Researching Public Libraries and the Social Web, 2006-2012." Iournal of Documentation $71(4): 632-49$.

Carr, Caleb T., and Rebecca A. Hayes. 2015. "Social Media: Defining, Developing, and Divining." Atlantic Journal of Communication 23 (1): 46-65.

Cavanagh, Mary F. 2016. “Micro-Blogging Practices in Canadian Public Libraries: A National Snapshot.” Lournal of Librarianship and Information Science 48 (3): 247-59.

Charnigo, Laurie, and Paula Barnett-Ellis. 2007. "Checking out Facebook.com: The Impact of a Digital Trend on Academic Libraries." Information Technoloau and Libraries 26 (1): 23-34.

Chen, Dora Yu-Ting, Samuel Kai-Wah Chu, and Shu-Qin Xu. 2012. "How Do Libraries Use Social Networking Sites to Interact with Users." Proceedinas of the Association for Information Science and Technologu 49 (1): 1-10.

Chen, Jason I., Gabriela D. Romero, and Marc S. Karver. 2016. "The Relationship of Perceived Campus Culture to Mental Health Help-Seeking Intentions." Iournal of Counselina Psuchologu 63 (6): 677-84.

Cheon, Jongpil, Sangno Lee, Steven M. Crooks, and Jaeki Song. 2012. "An Investigation of Mobile Learning Readiness in Higher Education Based on the Theory of Planned Behavior." Computers and Education 59 (3): 1054-64.

Chin, Wynne W. 1998. “The Partial Least Squares Approach to Structural Equation Modeling.” In Modern Methods for Business Research, edited by George A. Marcoulides. London: Psychology.

Chu, Samuel Kai-Wah, and Helen S. Du. 2013. “Social Networking Tools for Academic Libraries.” Journal of Librarianship and Information Science 45 (1): 64-75.

Chuttur, Mohammad Y. 2009. "Overview of the Technology Acceptance Model: Origins, Developments and Future Directions.” Working Papers on Information Systems 9 (37): 1-21. 
Comrey, Andrew L. 1973. A First Course in Factor Analysis. New York: Academic.

Dankowski, Terra. 2013. "How Libraries Are Using Social Media." American Libraries 44 (5): 38-41.

Davis, Fred D. 1989. "Perceived Usefulness, Perceived Ease of Use, and User Acceptance of Information Technology." MIS Ouarterly 13 (3): 319-40.

DeLone, W. H., and E. R. McLean. 1992. "Information Systems Success: The Quest for the Dependent Variable." Information Sustems Research 3 (1): 60-95.

Fasola, Omobolanle S. 2015. "Perceptions and Acceptance of Librarians towards Using Facebook and Twitter to Promote Library Services in Oyo State, Nigeria.” Electronic Libraru 33 (5): 870-82.

Fernandez, Joe. 2009. "A SWOT Analysis for Social Media in Libraries." Online 33 (5): 35-37.

Fishbein, Martin, and Icek Ajzen. 1975. Belief, Attitude, Intention, and Behavior: An Introduction to Theory and Research. Reading, MA: Addison Wesley.

Fornell, Claes, and David F. Larcker. 1981. "Evaluating Structural Equation Models with Unobservable Variables and Measurement Error." Journal of Marketina Research 18 (1): 39-50.

Hair, Joseph F., G. Tomas M. Hult, Christian Ringle, and Marko Sarstedt. 2014. A Primer on Partial Least Squares Structural Equation Modeling (PLS-SEM). Los Angeles: Sage.

Hair, Joseph F., Christian M. Ringle, and Marko Sarstedt. 2011. "PLS-SEM: Indeed a Silver Bullet.” Lournal of Marketing Theory and Practice 19 (2): 139-52.

Hsiao, Chun-Hua, and Kai-Yu Tang. 2014. "Explaining Undergraduates' Behavior Intention of e-Textbook Adoption: Empirical Assessment of Five Theoretical Models." Libraru Hi Tech 32 (1): 139-63.

Jones, Michael J., and Morgan Harvey. 2016. "Library 2.0: The Effectiveness of Social Media as a Marketing Tool for Libraries in Educational Institutions." Journal of Librarianship and Information Science. https://doi .org/10.1177/0961000616668959.

Joo, Soohyung, and Namjoo Choi. 2015. "Factors Affecting Undergraduates' Selection of Online Library Resources in Academic Tasks: Usefulness, Ease-of-Use, Resource Quality, and Individual Differences.” Libraru Hi Tech 33 (2): 272-91.

Lau, Adela S. M. 2011. "Hospital-Based Nurses' Perceptions of the Adoption of Web 2.0 Tools for Knowledge Sharing, Learning, Social Interaction and the Production of Collective Intelligence." Iournal of Medical Internet Research 13 (4): e92.

Lietzau, Zeth, and Jamie Helgren. 2011. US Public Libraries and the Use of Web Technologies, 2010. A Closer Look Report. Denver: Colorado State Library, Library Research Service.

Luo, Lili, Yuan Wang, and Lifeng Han. 2013. “Marketing via Social Media: A Case Study.” Libraru Hi Tech 31 (3): 455-66.

Madge, Octavia-Luciana, and Laura Coşerea. 2014. "The Facebook Challenge for Public Libraries in Romania." Studii de Biblioteconomie sii Stiinta Informarii 18:89.

Mansor, Yushiana, and Suby Rabea Adawiyah Idris. 2010. "Perceptions, Awareness and Acceptance of Library 2.0 Applications among Librarians at the International Islamic University Malaysia." Webology $7(2): 1-10$.

Neo, Emily, and Philip J. Calvert. 2012. "Facebook and the Diffusion of Innovation in New Zealand Public Libraries." Lournal of Librarianship and Information Science 44 (4): 227-37.

Park, Namkee, Raul Roman, Seungyoon Lee, and Jae Eun Chung. 2009. "User Acceptance of a Digital Library System in Developing Countries: An Application of the Technology Acceptance Model." International Journal of Information Management 29 (3): 196-209.

Phillips, Abigail L. 2015. "Facebooking It: Promoting Library Services to Young Adults through Social Media." Public Libraru Ouarterly 34 (2): 178-97. 
Podsakoff, Philip M., Scott B. MacKenzie, Jeong-Yeon Lee, and Nathan P. Podsakoff. 2003. “Common Method Biases in Behavioral Research: A Critical Review of the Literature and Recommended Remedies.” Iournal of Applied Psucholoau 88 (5): 879-903.

Rogers, Curtis R. 2012. Social Media, Libraries, and Web 2.0: How American Libraries Are Using New Tools for Public Relations to Attract New Users-Fourth Annual Survey, November 2011. Columbia: South Carolina State Library. https://dc.statelibrary.sc.gov/bitstream/handle/10827/7271/SCSL_Social_Media_Libraries_2011 .pdf?sequence $=1$.

Rutherford, Louise L. 2008. "Implementing Social Software in Public Libraries: An Exploration of the Issues Confronting Public Library Adopters of Social Software." Libraru Hi Tech 26 (2): 184-200.

Saeri, Alexander K., Claudette Ogilvie, Stephen T. La Macchia, Joanne R. Smith, and Winnifred R. Louis. 2014. "Predicting Facebook Users' Online Privacy Protection: Risk, Trust, Norm Focus Theory, and the Theory of Planned Behavior." Iournal of Social Psuchologu 154 (4): 352-69.

Sánchez-Franco, Manuel J., and José L. Roldán. 2015. "The Influence of Familiarity, Trust and Norms of Reciprocity on an Experienced Sense of Community: An Empirical Analysis Based on Social Online Services." Behaviour and Information Technoloay 34 (4): 392-412.

Schepers, Jeroen, and Martin Wetzels. 2007. "A Meta-analysis of the Technology Acceptance Model: Investigating Subjective Norm and Moderation Effects." Information and Management 44 (1): 90-103.

Shiri, Ali, and Dinesh Rathi. 2013. "Twitter Content Categorisation: A Public Library Perspective." Lournal of Information and Knowledae Management 12 (4): 1350035.

Smeaton, Kathleen, and Kate Davis. 2014. "Social Technologies in Public Libraries: Exploring Best Practice." Library Manaqement 35 (3): 224-38.

Solon, Olivia. 2018. “Facebook Says Cambridge Analytica May Have Gained 37M More Users' Data." Guardian, April 8. https://www.theguardian.com/technology/2018/apr/o4/facebook-cambridge-analytica-user -data-latest-more-than-thought.

Steiner, Sarah K. 2012. Strategic Planning for Social Media in Libraries. Chicago: ALA TechSource.

Taylor, Shirley, and Peter A. Todd. 1995a. “Assessing IT Usage: The Role of Prior Experience." MIS Ouarterly $19(4): 561-70$.

Taylor, Shirley, and Peter A. Todd. 1995b. "Understanding Information Technology Usage: A Test of Competing Models." Information Sustems Research 6 (2): 144-76.

Thong, James Y. L., Weiyin Hong, and Kar-Yan Tam. 2002. "Understanding User Acceptance of Digital Libraries: What Are the Roles of Interface Characteristics, Organizational Context, and Individual Differences?" International Journal of Human-Computer Studies 57 (3): 215-42.

Tohidinia, Zahra, and Mohammad Mosakhani. 2010. "Knowledge Sharing Behaviour and Its Predictors." Industrial Management and Data Sustems 110 (4): 611-31.

Tomlin, M. 2014. “Using Facebook to Market Libraries.” In Marketing with Social Media: A LITA Guide, edited by B. C. Thomsett-Scott. Chicago: American Library Association.

Vucovich, Lee A., Valerie S. Gordon, Nicole Mitchell, and Lisa A. Ennis. 2013. "Is the Time and Effort Worth It? One Library's Evaluation of Using Social Networking Tools for Outreach.” Medical Reference Services Ouarterly 32 (1): 12-25.

Xie, Qijun, Wei Song, Xiaobao Peng, and Muhammad Shabbir. 2017. "Predictors for e-Government Adoption: Integrating TAM, TPB, Trust and Perceived Risk.” Electronic Library 35 (1): 2-20.

Xu, Jingjun David, Izak Benbasat, and Ronald T. Cenfetelli. 2013. "Integrating Service Quality with System and Information Quality: An Empirical Test in the e-Service Context." MIS Ouarterly 37 (3): 777-94. 
Soohyung Joo: assistant professor in the School of Information Science, University of Kentucky. Joo obtained a PhD in information studies from the University of Wisconsin-Milwaukee. His main research areas include human-information interaction, data science, data management and services, and social media. His research work has been published in information science journals, including the Journal of the Association for Information Science and Technology, Information Processing and Management, and The Electronic Library. Email: soohyung.joo@uky.edu.

Namjoo Choi: associate professor in the School of Information Science, University of Kentucky. Choi received his PhD in informatics from the University at Albany, State University of New York. His research interests include online communities, free/libre open source software, social media, and technology adoption and postadoption. His research work has been published in top-tier journals in both library science and information systems fields such as IEEE Software, Journal of the Association for Information Science and Technology, Library and Information Science Research, and Journal of the Association for Information Systems. Email: namjoo.choi@uky.edu.

Lindsey M. Harper: staff librarian/scholarly communication specialist, Marshall University Libraries. Harper received her MS in library science from the School of Information Science at the University of Kentucky in 2017, and she received her MA in psychology from Marshall University in 2015. Her research interests include information-seeking behaviors, data-sharing behaviors, social psychology, knowledge organization, social media, diversity, and gender. Email: harper166@marshall.edu. 